\title{
TRANSNATIONAL PRIVATE REGULATORY GOVERNANCE: AMBIGUITIES OF PUBLIC AUTHORITY AND PRIVATE POWER
}

\author{
PEER ZUMBANSEN*
}

\section{INTRODUCTION}

The proliferation of private norm-making, that is, the creation of legally binding rules outside of the institutional, state-based systems of rule-setting, very forcefully accentuates the dilemma of the modern nation state's exhaustion in an era of globalization. Seen against the background of the law-as-victim thesis, the ubiquitous forms of "private ordering," both inside and outside of the nation-state, are regularly read as signs of the erosion processes, which allegedly characterize the general fate of the sovereign state in the global era and find a particularly striking illustration in the relativization of the state's authority to administer and to control the institutions of norm-creation. ${ }^{1}$ However, from a sociological perspective, the current interest of so-called governance theories ${ }^{2}$ in "social norms" falls squarely into the discipline's

Copyright (C) 2013 by Peer Zumbansen.

This article is also available at http://lcp.law.duke.edu/.

* Licence en droit (Paris); State Law exam (Frankfurt); Ph.D law (Frankfurt), Habilitation (Frankfurt); LL.M. (Harvard). Professor of Law and Canada Research Chair in Transnational Economic Governance and Legal Theory. Director, Critical Research Laboratory in Law \& Society. Osgoode Hall Law School, York University, Toronto, Canada. Email: PZumbansen@ osgoode.yorku.ca. This paper is based on a lecture at the "Public Dimensions of Contract" Conference, Villa Vigoni, Italy, November 9-10, 2011. Expanded versions were presented at the "Legitimacy of Private Transnational Governance by Contract" Workshop, organized by Claire Cutler and Fabrizio Cafaggi under the auspices of the Hague Institute for the Internationalisation of Law [HiiL], the European University Institute and the University of Victoria and at the "Postnational Rulemaking" Conference at the University of Amsterdam in September 2012. I am grateful to Marc Amstutz, Fabrizio Cafaggi, Daniela Caruso, Ed Cohen, Hugh Collins, Claire Cutler, Isabel Feichtner, Hanoch Dagan, Bertram Lomfeld, Ralf Michaels, Dan Wielsch, and Cynthia Williams for generous feedback. All errors remain mine.

1. For a distinctly skeptical perspective, see Johannes Köndgen, Privatisierung des Rechts: Private Governance zwischen Deregulierung und Rekonstitutionalisierung, 206 ARCHIV FÜR DIE CIVILISTISCHE PRAXIS [ACP] 477, 477-525 (2006) (Ger.).

2. See generally Thomas Vesting, Die Staatsrechtslehre und die Veränderung ihres Gegenstandes: Konsequenzen von Europäisierung und Internationalisierung, 63 VERÖFFENTLICHUNGEN DER VEREINIGUNG DER DEUTSCHEN STAATSRECHTSLEHRER 41 (2003) (Ger.); KARL-HEINZ LAdEUR, DAS UMWELTRECHT DER WisSENSGESELLSCHAFT (1995) (presenting a comprehensive theory to describe the transformation of the state in the face of complex societal challenges); Karl-Heinz Ladeur, Die rechtswissenschaftliche Methodendiskussion und die Bewältigung des gesellschaftlichen Wandels, 64 RABELS ZEITSCHRIFT FÜR AUSLÄNDISCHES UND INTERNATIONALES PRIVATRECHT [RABELSZ], 60, 
concern with the study of societal differentiation processes. Such accounts play a crucial role in informing legal scholars' inquiries into the nature and consequences of private norm-creation processes for the study of law in general. ${ }^{3}$

Compressed into a relatively small space then, we can discern some of the central challenges to current legal thinking: under the impression of an unquestionably deep-running transformation of forms of public and private ordering, lawyers seek explanations by contextualizing these developments. What they find are impressive accounts of globalization processes, which have prompted a considerable number of social science disciplines to fundamentally rethink their analytical categories and conceptual frameworks. In this context, legal scholars find that their own accounts of the growing limits of regulatory capacity in view of, for example, border-crossing environmental or security concerns, coalesce with observations made by political scientists, sociologists, geographers, or anthropologists regarding a fundamental decentralization and privatization of norm-creation and legal-political decision-making.

For law, to be sure, there is much at stake, as this multidisciplinary diagnosis strongly suggests lawyers' need to rethink the proper foundations, boundaries and-in fact-the nature of their object itself. The rich accounts of legal pluralism and non-state-based norm-creation, which are central to current depictions of the shift "from government to governance," can be read as strong signals that law itself has an identity crisis, a crisis regarding its own nature and function. It is important to note, however, that accounts of a co-existence of legal and non-legal forms of social regulation, while proliferating under the impression of reduced state capacity to effectively regulate transnational issues, have always been part of the central make-up of legal theory. Early anthropological and legal theoretical accounts of the extensive efficacy of "informal" orders should have alerted lawyers a long time ago to the tension between law and non-law, which arguably lies at the heart of any legal system.

This article suggests a revisiting of the field of lex mercatoria, the body of norms associated with a transnational "law merchant." These norms and their surrounding institutions and processes, although much contested, have forever assumed a prominent place in studies of private ordering, driven particularly by the fact that the lex mercatoria reaches far, far back into past centuries of economic globalization, and is thus seen as testifying to both the reality and the viability of transnational law "beyond the state." ${ }^{4}$ In light of the concerns raised

60-103 (2000) (Ger.) (arguing for a methodological shift in legal theory to account for the integration of uncertainty into legal reasoning).

3. See generally Louis Jaffe, Law Making by Private Groups, 51 HARV. L. REV. 201, 201-53 (1937) (describing the significance of private norm-creation); FERDINAND KIRCHHOF, PRIVATE RECHTSETZUNG (1987) (presenting an overview of private norm-setting in the German legal context).

4. See, e.g., Ralf Michaels, The True Lex Mercatoria: Law Beyond the State, 14 IND. J. GLOBAL LEgAl STUD. 447, 447-68 (2007); EMMANUEL GAILLARD, LEgAL THEORY OF INTERNATIONAL ARBITRATION 35-66 (2010) (arguing emphatically for the existence of an "autonomous arbitral legal order"). 
by lawyers regarding the limits of law and legal norm-creation in the context of globalization, the pressing question concerning the lex mercatoria appears to be that of the possibility of an autonomous legal order, that is, of a functioning legal system, which is itself not grounded in the nation-state's institutionalized norm-creation processes. ${ }^{5}$ It is against this background of the still contested consequences of globalization for law that it becomes clear how much of the debate around the lex mercatoria, and around the autonomy and scope of this transnational law merchant, is ill-directed and of little analytical value. In fact, much of the polemics that surround the "legal" nature of the lex mercatoria, its "true" independence, and its autonomy from the nation-state, ${ }^{6}$ prevent us from turning our attention to something arguably much more important, namely why we should even care so much about all this.

What follows here should not be read as a continuation of or yet another contribution to what has grown into a highly differentiated and detailed debate about the legal quality of the lex mercatoria. ${ }^{8}$ Instead, the task here is to position the lex mercatoria-once again ${ }^{9}$ - in the context of a still inconclusive investigation into the consequences of globalization for law. ${ }^{10}$ From this perspective, our interest in the lex mercatoria is driven by a more general concern with the nature and the politics of law and legal norm-creation in the "post-national" constellation." Thus, the much disputed connection between

5. For a distinction between "traditionalists" and "transnationalists," see KLAUS PETER BERGER, THE CREEPING CODIFICATION OF THE NEW LEX MERCATORIA (2d ed. 2010).

6. See generally Albrecht Cordes, The Search for a Medieval Lex Mercatoria, 5 OXFORD U. COMP. L. F. (2003), http://ouclf.iuscomp.org/articles/cordes.shtml; Hans-Joachim Mertens, Lex Mercatoria: A Self-applying System Beyond National Law?, in Global LAw WithouT A STATE 31, 31-43 (Gunther Teubner ed., 1997).

7. But see Karsten Schmidt, Lex mercatoria: Allheilmittel? Rätsel? Chimäre?, in GLOBALISIERUNG UND RECHT: BEITRÄGE JAPANS UND DEUTSCHLANDS ZU EINER INTERNATIONALEN RECHTSORDNUNG IM 21. JAHRHUNDERT 153, 162-63 (Junichi Murakami, HansPeter Marutschke \& Karl Riesenhuber eds., 2007) (highlighting the deficiencies of the lex mercatoria in comparison to codified legal rules); Nikitas E. Hatzimihail, The Many Lives-and Faces-of Lex Mercatoria: History as Genealogy in International Business Law, 71 LAW \& CONTEMP. PROBS. 169, 169-90 (Summer 2008) (revisiting two of the lex mercatoria's founding figures, Clive Schmitthoff and Berthold Goldman, who espoused the idea of a unique regulatory framework for transnational commerce).

8. See Thomas Schultz, Some Critical Comments on the Juridicity of Lex Mercatoria, in 10 Y.B. PRIVATE INT'L L. 667, 667-710 (Andrea Bonomi \& Paul Volken eds., 2008); see also the provocative study by GAILLARD, supra note 4 , at 35-51.

9. See generally Peer Zumbansen, Piercing the Legal Veil: Commercial Arbitration and Transnational Law, 8 EUR. L. J. 400, 400-32 (2002), reprinted in ECONOMICS OF COMMERCIAL ARbitration AND DispUte RESOLUTION 464-96 (Econ. Approaches to Law 21, Orley C. Ashenfelter \& Radha K. Iyengar eds., 2009).

10. See, e.g., Marc Amstutz, Zwischenwelten: Zur Emergenz einer interlegalen Rechtsmethodik im europäischen Privatrecht, in RECHTSVERFASSUNGSRECHT. RECHT-FERTIGUNG ZWISCHEN PRIVATRECHTSDOGMATIK UND GESELLSCHAFTSTHEORIE 213-37 (Christian Joerges \& Gunther Teubner eds., 2003); Marc Amstutz, The Letter of the Law: Legal Reasoning in a Societal Perspective, 10 GERMAN L.J. 361, 361-82 (2009); Marc Amstutz, Métissage. Zur Rechtsform in der Weltgesellschaft, in EUROPÄISCHE GESELLSCHAFTSVERFASSUNG: ZUR KONSTITUTIONALISIERUNG SOZIALER DEMOKRATIE IN EUROPA 333-51 (Andreas Fischer-Lescano et al. eds., 2009).

11. See generally Jürgen Habermas, The Postnational Constellation. Political 
the multidisciplinary study of globalization and legal theory merits further attention. ${ }^{12}$ Part of this inquiry includes connecting concerns within the legal discourse with concurring investigations by other disciplines into the changed role of the state. ${ }^{13}$ Under the impression of a forcefully emerging sociological discourse around the specific quality of a "world knowledge society," a particular task lies in critically revisiting some of the long-standing theoretical categories and distinctions such as that between public and private, state and society, and national and international. ${ }^{14}$ In the context of a knowledge society, distinctions, demarcations, and boundary-settings are the foremost instruments of creating reality through meaning. In an argumentative, discursive context, meaning is constructed, deconstructed, reconstructed, and reconstituted through language and contestation. The lex mercatoria offers a welcome opportunity in this context, as a closer scrutiny of the arguments made against it (including its legal nature and its autonomous status) as well as in its defense, promises insights into the constitutive functions of such arguments. An analysis of the arguments made against and in favor of the lex mercatoria should allow us to better ascertain the construction of the societal spheres of action as well as of the legal spaces associated with and constituted by such arguments.

Characterizing the lex mercatoria as "private law," then, has particular connotations and consequences for its overall situation in a legal-regulatory context. The connotations of the qualification "private" need to be unfolded to better understand the place and function of this body of norms in a larger framework of legal (and, arguably, political) ordering. In particular, because a legal theory of globalization is still outstanding, it is necessary to critically analyze and contextualize those concepts that, for better or for worse, are relied upon in the process of applying established legal frameworks within the transnational realm. ${ }^{15}$ A concluding section of this article will sketch the outline of a sociologically informed method of legal thought under the heading of "transnational legal pluralism." On the one hand, such an approach might offer some insights into the larger connotations of categories applied to the lex mercatoria, such as public and private or law and non-law. On the other hand, transnational legal pluralism might facilitate a better understanding of the nature of law in the continuously unfolding context of globalization. ${ }^{16}$

ESSAYS (Max Pensky ed. \& trans., 2001).

12. See infra Part II. For an analysis from the perspectives of criminal and public law, see Ulrich Sieber, Rechtliche Ordnung in einer Globalen Welt, 41 RECHTSTHEORIE 151, 151-98 (2010) (Ger.).

13. Saskia Sassen, Globalization or Denationalization? 10 REV. INT'L POL. ECON. 1, 1-22 (2003) (emphasizing the state's agency in globalization processes); Sally Engle Merry, Anthropology, Law, and Transnational Processes, 21 AnN. ReV. ANTHROPOLOGY 357, 357-79 (1992) (highlighting the coexistence and interpenetration of hard and soft norms in governance).

14. See generally KARL-HEINZ LADEUR, NEGATIVE FREIHEITSRECHTE UND Gesellschaftliche Selbstorganisation (2000); Helmut Willke, SMART Governance: Governing the Global KNOwledge Society 34 et. seq. (2007); Nico Stehr, KnOwledge SOCIETIES (1994).

15. See infra Part III.

16. See infra Part IV. 


\section{LAW AND GLOBALIZATION: VictiM, COLLATERAL DAMAGE, OR MOTOR?}

It is striking that the formula "law and globalization" contains not one, not two, but altogether at least three unknowns. First, it is undisputed that notwithstanding numerous, often quite fruitful definitions of globalization, the term still operates as a conundrum, as a term depicting an analytical and conceptual framework grounded in several disciplines and discourses at once, and as such resists a clear definition. And yet, against the background of the continuously growing literature around the concept, emerging from a host of different disciplinary starting points and perspectives ${ }^{17}$ our interest shall here be focused in particular on law and legal categories. From that perspective, however, a second unknown comes into view in a prominent way, namely the relationship between globalization and law. For the law, the advent of globalization, arguably, raises questions of existential significance. In other words, under the spectre of globalization, law is faced with the prospect of its own demise ${ }^{18}$ most definitely due to the modern association of law with the state, a state that in the present era of globalization has come under great pressure. This association results in the making of an argument de maiore ad minus, whereby the perceivably dramatic impact of globalization processes on the state is seen to directly predetermine the transformation of law, itself resulting in nothing less than a far-reaching weakening, if not implosion, of law. ${ }^{19}$ Law, put in relation to globalization, is then portrayed as a unified body "under attack," a body of norms, institutions, and processes in need of either being protected against or adapted to the pressures of globalization.

Much suggests, however, that the formula holds a third, regularly neglected unknown. With a view to the long-standing sociological insights into the parallel worlds of legal and non-legal forms of social regulation, of formal and informal systems of legal ordering, there are good reasons to read the present iterations concerning the significance of globalization processes as illustrative of a new phase of legal evolution. This would characterize law itself as an object of investigation and scrutiny. ${ }^{20}$ Such scrutiny would have to rescue law from two

17. See the brilliant exposition by David Held \& Anthony McGrew, The Great Globalization Debate: An Introduction, in THE GLOBAL TRANSFORMATIONS READER: AN INTRODUCTION TO THE Globalization Debate 1, 1-50 (David Held \& Anthony McGrew eds., 2d ed. 2003); another very helpful introduction is offered by MANFred B. STEGER, Globalization. A VERY SHORT INTRODUCTION (2d ed. 2009).

18. An impressive testament from the point of view of a state-based theory of law is provided in the monographical study by STEPHAN HOBE, DER OFFENE VERFASSUNGSSTAAT ZWISCHEN SOUVERÄNITÄT UND INTERDEPENDENZ. EINE STUDIE ZUR WANDLUNG DES DEUTSCHEN STAATSBEGRIFFS DER DEUTSCHSPRACHIGEN STAATSLEHRE IM KONTEXT INTERNATIONALER INSTITUTIONALISIERTER KOOPERATION (1998).

19. See generally UDO DI FABIO, DER VERFASSUNGSSTAAT IN DER WELTGESELLSCHAFT (2001); Udo Di Fabio, The Present and Future Meaning of the State and the Role of the Federal Constitutional Court-Interview, 2 GERMAN L.J. 20 (2001), available at http://www.germanlawjournal. com/index.php?pageID=11\&artID=20.

20. See Gunther Teubner, The King's Many Bodies: The Self-Deconstruction of Law's Hierarchy, 
dominant claims regarding law's fate in an era of globalization. One view insists on emphasizing and lamenting the alleged weakness of (the state's) regulatory law that finds its most persuasive illustration in the triumphant proliferation of private norm-setting ${ }^{21}$ and suggests that law cannot escape death by suffocation in the oxygen-free atmosphere of globalization. The competing view presents a radicalized version of the first: it holds up an idealized image of the nation-state and its legal order as unified, hierarchical, and coherent-only to suffer from the undermining and corrosive effects of globalization. From this perspective, globalization is depicted as a process that emerges in (a particular) time and from outside the nation-state to destroy the state-based legal order. ${ }^{22}$ Such depictions of law "as it lay dying" suggest, above all, that law would enjoy blissful health and strength if only it had been protected from globalization. What happened?

The remainder of this article will seek to unfold the following three working hypotheses:

1. Law as an unknown must be understood and reconstructed in the context of globalization.

2. Law, as thought of in conjunction with the nation-state, must today be understood as law after the welfare state, but not as law without the state.

3. The question regarding the future of law in a context of globalization is one of legal methodology.

As suggested, the lex mercatoria-depicted by some as a shining example and proof of the existence of an "autonomous arbitral legal order" 23 and by others as whipping boy for legal theories that cling to the irresolvable nexus between law and the state ${ }^{24}$ - shall offer an anchor point for a closer analysis and discussion of the three hypotheses.

\section{III}

\section{THE TREACHEROUSLY "PRIVATE" NATURE OF AUTONOMOUS LEGAL ORDERS}

\section{A. Lex Mercatoria: "Intervention" Versus "Autonomy"}

In the context of international commercial arbitration, references to the lex mercatoria regularly target the rules and conflict resolution mechanisms of border-crossing commercial transactions. Emphasis is placed on flexibility, relevance, and discretion as the main characteristics of a system of arbitral tribunals that has been initiated and constituted by the commercial partners

31 LAW \& SOC'Y REV. 763, 763-88 (1997).

21. See David Weissbrodt \& Muria Kruger, Norms on the Responsibilities of Transnational Corporations and Other Businesses Enterprises with Regard to Human Rights, 97 AM. J. COMP. L. 901, 901-22 (2003); see generally A. Claire Cutler, PRIVATE POWER AND Global Authority: TRANSNATIONAL MERCHANT LAW IN THE GLOBAL POLITICAL ECONOMY (2003).

22. See the discussion of this description by Vesting, supra note 2.

23. See, e.g., GaIllard, supra note 4.

24. See, e.g., Cordes, supra note 6. 
themselves. ${ }^{25}$ This classification hints at a number of significant differences between state- and non-state-based rules and conflict resolution institutions. The implied qualification of the lex mercatoria as autonomous is based, in part, on the argument that the contracting partners themselves bring the arbitral order into being ${ }^{26}$ and in part on the thesis that these parties are themselves the authors of the applicable rules. ${ }^{27}$ The underlying, general implication, however, reaches higher: the claim that the lex mercatoria constitutes an autonomous legal order contains itself the argument that there can and should be privately constituted regulatory systems, independent from the state. ${ }^{28}$ We shall see that this claim, which is altogether not very different from positions taken by legal pluralists, is ultimately vulnerable to ideological hijacking and instrumentalization.

From the perspective of a politically progressive law and society approach, the claim for an autonomous legal order can be read as a plea for a more context-sensitive and ultimately "learning" interaction between formal and informal norm-creating processes. Such an approach would not necessarily have to imply the existence of a law-less realm of societal interaction, but would still remember the insights from early institutional economics and legal realism, namely that markets never exist "as such," but are legally constituted spheres of exercised power. ${ }^{29}$ At the same time, the assertion of an autonomous legal order in the context of embracing social norms as legitimate expressions of private ordering and conflict resolution among sovereign market participants implies a different understanding of the relationship between public and private, and between the state and the market. The latter position is wrapped up in an elaborate and far-reaching critique of judicial "interventions" into the allegedly consensual and arguably private dealings among market participants, a critique that harks back to the U.S. Supreme Court's 1905 decision in Lochner v. New

25. Klaus Peter Berger, The New Law Merchant and the Global Market Place: A 21st Century View of Transnational Commercial Law, in THE PRACTICE OF TRANSNATIONAL LAW 1, $20-21$ (Klaus Peter Berger ed., 2001); Dieter Schmidtchen, Lex Mercatoria und die Evolution des Rechts, in VEREINHEITLICHUNG UND DIVERSITÄT DES ZIVILRECHTS IN TRANSNATIONALEN WIRTSCHAFTSRÄUMEN 1, 21 (Claus Ott \& Hans-Bernd Schäfer eds., 2002) (highlighting the fact that the lex mercatoria does not depend on a legislator).

26. See Klaus Günther, Rechtspluralismus und universaler Code der Legalität: Globalisierung als rechtstheoretisches Problem, in DIE ÖFFENTLICHKEIT DER VERNUNFT UND DIE VERNUNFT DER ÖFFENTLICHKEIT: FESTSCHRIFT FÜR JÜRGEN HABERMAS 539 (Lutz Wingert \& Klaus Günther eds., 2001).

27. Margaret L. Moses, The Principles And Practice of InTERnational Commercial ARBITRATION 1 (2008) ("Arbitration is a private system of adjudication. Parties who arbitrate have decided to resolve their disputes outside of any judicial system.").

28. See Gunther Teubner, Breaking Frames: The Global Interplay of Legal and Social Systems, 45 AM. J. CoMP. L. 145, 145-69 (1997); see also Gralf-Peter Calliess, Lex Mercatoria: A Reflexive Law Guide To An Autonomous Legal System, 2 GERMAN L.J. 17 (2001), available at http://www.germanlawjournal.com/article.php?id=109.

29. See generally JOHN R. COMMONS, LEGAL FOUNDATIONS OF CAPITALISM 48-50 (Transaction Publishers 1995) (1924); Robert L. Hale, Coercion and Distribution in a Supposedly Non-Coercive State, 38 Pol. SCI. Q. 470, 470-94 (1923); Morris R. Cohen, Property and Sovereignty, 13 CoRNELL L. Q. 8, 830 (1927). 
York ${ }^{30}$ itself evoking a century's worth of ideological struggle over the place of courts in market regulation. In this contemporary, anti-judicial discourse, courts are rejected to the degree that they aspire to social engineering, social policy, and law making. More recently, courts are dismissed for their alleged lack of technical expertise, especially as regards the intricate details of modern-day commercial and corporate contracting usages. Hence, judges should adhere to the application of simple default rules and otherwise defer to the private autonomy of the contracting parties. ${ }^{31}$

This last position raises the question as to how we are to think of rights as instruments available to market actors. Where should these rights emerge from if not from an encompassing legal order that results in contract and property rights regulating relations between members of a legal community? By contrast, the implied image of a (Hayekian) framework order, which holds on reserve a legal enforcement system for the occasion that private ordering fails, continues to rest on the assumption that rights can emerge out of nowhere. The notion of the state and the legal system as emergency mechanisms is based on the belief that the legal system can be invoked only when the market interactionincluding the exercise of property rights-defaults. ${ }^{32}$ That belief stands, to be sure, in stark contrast to the contention that markets are legally regulated spheres. The surprising emergence of rights in a professedly self-regulatory system described as a natural and private order is part of an argument that wants it all. A quasi-natural sphere of uninhibited societal interaction, disturbed only in cases of emergency (of which kind, we may ask) when the judicial system is called upon to intervene, remains a strangely impossible beast. But it is an intriguing and, as implied by the discourse around the autonomous nature of the lex mercatoria, a highly suggestive one.

The distinction between law and non-law, which emerges in the context of the lex mercatoria, thus appears as directly tied to competing understandings of market order and "intervention." But, as noted, the legal sociological or legal pluralist recognition of informal legal orders ${ }^{33}$ and of the prevalence of a vast number of binding commercial rules and customs ${ }^{34}$ not created by the state renders the opposition between progressives and conservatives ambiguous. Although both may emphasize the existence of norms "outside" of the state, they draw different conclusions from this finding for their understanding of legal systems as such, and this makes even the demarcation between

30. Lochner v. New York, 198 U.S. 45, 53 (1905).

31. See, e.g., ERIC POSNER, LAW AND SOCIAL NORMS 159 (2000).

32. For a convincing critique, see David Charny, Illusions of a Spontaneous Order: "Norms" in Contractual Relationships, 144 U. PA. L. REV. 1841, 1841-58 (1996).

33. See generally Eugen EHRLiCH, Fundamental PRINCIPLES OF THE SOCIOLOGY OF LAW (Walter L. Moll trans., 1936); H. W. ARTHURS, 'WiTHOUT THE LAW': ADMINISTRATIVE JUSTICE AND LEGAL PLURALISM IN NINETEENTH-CENTURY ENGLAND (1985).

34. An excellent summary is provided by BERGER, supra note 5 . 
progressives and conservatives considerably more difficult than in the context of allegedly clear ideological confrontation.

\section{B. Contract Redux}

Seen in this light, then, our interest in the lex mercatoria directs us deep into legal sociological accounts of "technical" (official) and "cultural" (unofficial) legal orders, ${ }^{36}$ while—at the same time-leading us back to legal-political tensions that have long characterized the evolution of law within the nationstate. These tensions are associated with demarcations between public and private spaces, between state and society, and between politics and market. But, underneath these demarcations are conceptualizations of autonomy and intervention, ${ }^{37}$ individualism and altruism, ${ }^{38}$ and autonomy and care ${ }^{39}$-all of which point to deeper-running questions of legitimate social ordering. In other words, ordering paradigms such as the distinctions between public and private or state and society function as constituting frameworks within which questions of legitimacy are being addressed.

This background goes a long way in explaining the obvious stakes in the debate around the lex mercatoria. The contestation of the field's autonomous nature, the authorship and quality of its norms, and its adjudication mechanisms point to the much more contentious views regarding the competence and legitimacy of private actors to initiate and institutionalize a proper system of legal regulation. As we have seen, the conceptual embrace of a purportedly autonomous, transnational order may too quickly cut the ties between the unavoidably recurring conflicts over power, bargaining asymmetry, and thirdparty interests, ${ }^{40}$ and long-standing reflections on the relationship between state and society-as representations of a particular, historical constellation of public versus private ordering.

This is particularly noticeable in the area of contractual governance, a field of societal interaction that is central to the liberal paradigm of Western law ${ }^{41}$ and that offers the dominant ordering paradigm for the lex mercatoria. The

35. See, e.g., Lochner, 198 U.S. at 45-76 (illustrating the juxtaposition of Justice Peckham's embrace of a constitutionally protected free-market doctrine on the one hand and dissenting Justice Holmes' insistence on the ideological indeterminacy of the constitution on the other).

36. See Annelise Riles, A New Agenda for the Cultural Study of Law: Taking on the Technicalities, 53 BUFF. L. REV. 973, 973 (2005).

37. MORITZ RENNER, ZWIngEndes Transnationales Recht. ZUR STRUKTUR DER WIRTSCHAFTSVERFASSUNG JENSEITS DES STAATES 24-90 (2011).

38. Duncan Kennedy, Form and Substance in Private Law Adjudication, 89 HARV. L. REV. 1685, 1685 (1976).

39. Günter Frankenberg, Why Care?-The Trouble with Social Rights, 17 CARdOzo L. REV. 1365, 1371 (1996); Jürgen Habermas, Paradigms of Law, 17 CARDOZO L. REV. 771, 775 (1996).

40. This point is emphasized by Gunther Teubner, 'Global Bukowina': Legal Pluralism in the World Society, in GlOBAL LAW without A STATE, supra note 6, at 27-28.

41. See generally FRANZ WIEACKER, PRIVATRECHTSGESCHICHTE DER NEUZEIT UNTER BESONDERER BERÜCKSICHTIGUNG DER DEUTSCHEN ENTWICKLUNG (1967); KARL RENNER, THE Institutions of PRivate LAW AND Their Social Functions (O. Kahn-Freund ed., Agnes Schwarzschild trans., 1949). 
forgetfulness characterizing the euphoria of many of those adhering to the autonomy theory of the lex mercatoria ${ }^{42}$ perpetuates itself into their theories of contract governance. Allegedly freed now from decades of judicial "interventions" into contractual bargains among sovereign private actors, ${ }^{43} \mathrm{a}$ promising space of inhibited private ordering is opening, far away from conflicts over the social context of contracting. But because contract is so central to the liberal model of law, its simplified reception and conceptualization in the transnational context has significant consequences for the encompassing understanding of law's relation to society as such. Rather than building on the wealth of historical, ${ }^{44}$ sociological, ${ }^{45}$ anthropological, ${ }^{46}$ economic, ${ }^{47}$ and "legalcritical" analysis of contractual governance, ${ }^{48}$ what is received in this reading of the "new" transnational order is an oversimplified, stripped-down, mechanical concept of contracting. This reductionist reception of contract theory is guilty not just of ignoring the aforementioned theoretical legacies, but also of bypassing more recent engagements with the intricate functions of contractual governance in complex societal settings. ${ }^{49}$ Little, indeed, suggests that we should simply go back to an ideal of a "private law society," itself determined, above all, by the free bargains amongst free agents. ${ }^{50}$ Considering the historically evolved complexity of the "embeddedness of contract,"

42. See generally FOUCHARD, GAILLARD, GOLDMAN ON INTERNATIONAL COMMERCIAL ARBITRATION (Emmanuel Gaillard \& John Savage eds., 1999).

43. Robert Scott, The Death of Contract Law, 54 U. ToRonTo L.J. 369, 379 (2004) ("Casual observation thus points to the conclusion that the newly expanded contract law has failed to provide parties with the reliable, cost-effective rules that they prefer for enforcing and interpreting their agreements. Replacing common law rules with vague standards may permit courts to decide difficult cases, but at a substantial cost in the uncertainty of contractual obligations.").

44. See, e.g., RENNER, supra note 41.

45. See, e.g., Stewart Macaulay, Non-Contractual Relations in Business: A Preliminary Study, 28 AM. SOC. REV. 55, 55-67 (1963).

46. See, e.g., John P. Esser, Institutionalizing Industry: The Changing Forms of Contract, LAW \& SOC. INQUIRY 593, 593-629 (1996); Riles, supra note 36, at 989 (arguing that her account will already reach beyond a sociological or anthropological one).

47. See, e.g., Hale, supra note 29, at 470-94.

48. See, e.g., Morris R. Cohen, The Basis of Contract, 46 HARV. L. Rev. 553, 553-92 (1932).

49. As argued by a number of private law theory scholars, contract arrangements can bear the potential for an intricate combination of hard and soft, fixed and adaptable, "learning" elements to structure bi- and multi-lateral relations. See, e.g., Ian R. Macneil, Relational Contract: What We Do and Do Not Know, 1985 WIS. L. REV. 483, 483-525; Esser, supra note 46, at 593-629; David Campbell, Reflexivity and Welfarism in the Modern Law of Contract, 20 OXFORD J. LEGAL STUD. 477, 477-98 (2000); Roy Kreitner, Frameworks of Cooperation: Competing, Conflicting, and Joined Interests in Contract and Its Surroundings, 6 THEORETICAL INQUIRIES L. 59, 59-111 (2005); Peer Zumbansen, The Law of Society: Governance Through Contract, 14 IND. J. GLOBAL LEGAL STUD. 191, 191-233 (2007).

50. For such a plea, see generally FRANZ BYDLINSKI, DAS PRIVATRECHT IM RECHTSSYSTEM EINER "PRIVATRECHTSGESELLSCHAFT" (1994); for a critical response, see generally Thomas Vesting, Wiederkehr der bürgerlichen Gesellschaft und ihres Rechts? Zur neueren Diskussion über das Verhältnis von öffentlichem Recht und Privatrecht, in BÜRGERLICHES GESETZBUCH 1896-1996. RINGVORLESUNG DER JURISTISCHEN FAKULTÄT AUGSBURG (Hans Schlosser ed., 1997).

51. See generally Franz Böhm, Privatrechtsgesellschaft und Marktwirtschaft, 17 ORDO: JAHRBUCH FÜR DIE ORDNUNG VON WIRTSCHAFT UND GESELLSCHAFT [ORDO] 75, 75-151 (1996) (Ger.) (arguing for a concept of connected political and economic autonomy in the tradition of the economic 
the market as a naturally evolving sphere carry a particularly provocative scent. Central to the reductionist model of contractual governance is the emphasis on governing contracts, or "governance through contract," as key instrument of private ordering relations, ${ }^{52}$ the blind spot of this bias is the practice, within the judiciary and in theory, of "governance of contracts." The latter expresses itself, on the one hand, through the legal embeddedness of contracts in judicial materialization processes, ${ }^{53}$ and through the function of contract in an embedding political and societal economy, on the other. ${ }^{54}$ The plea for an autonomous transnational legal order thus seems part of an exaggerated demarcation of the transnational space from that of the nation-state ${ }^{55}$ and results in a wholesale rejection of the learning experiences that have been made over time within the complex relationship between state and society, public and private, and law and non-law. Another consequence of the simplification of contract is, as we have seen, an endorsement of an oversimplified idea of markets, which itself results in problematic assessments of the nature and the causes of "crisis." Even today, in the sobering presence of unmanageable private (and public) debt, brought about in a frenzy of financial liberalization and credit taking, the skepticism vis-à-vis the "interventionist" state looms large, ${ }^{57}$ and even development discourses still appear to be endorsing a simple world view of socially and politically de-contextualized concepts of contractual freedom and property rights. ${ }^{58}$ Such an unbroken belief in the self-regulatory

school of ordo-liberalism); Rudolf Wiethölter, Privatrecht als Gesellschaftstheorie?, in FUNKTIONSWANDEL DER PRIVATRECHTSINSTITUTIONEN. FESTSCHRIFT FÜR LUDWIG RAISER ZUM 70. GEBURTSTAG (Fritz Baur et al. eds., 1974). For a critique of this position within corporate law, see Peer Zumbansen, Rethinking the Nature of the Firm: The Corporation as a Governance Object, 35 SEATTLE U. L. REV. 1469, 1469-98 (2012).

52. Robert E. Scott \& George G. Triantis, Anticipating Litigation in Contract Design, 115 YALE L.J. 814, 820 (2006).

53. See, e.g., Gunther Teubner, Ein Fall von struktureller Korruption? Die Familienbürgschaft in der Kollision unverträglicher Handlungslogiken (BVerfGE 89, 214 ff.), 83 KRITISCHE VIERTELJAHRESSCHRIFT FÜR GESETZGEBUNG UND RECHTSWISSENSCHAFT [KRITV] 388, 388-404 (2000) (Ger.) (highlighting the challenges of a court's regulatory intervention into social relations that are not governed by a single set of rationalities); but cf., Uwe Diederichsen, Die Selbstbehauptung des Privatrechts gegenüber dem Grundgesetz, JURA 57, 57-64 (1997).

54. See generally Peer Zumbansen, Introduction: Private Ordering in a Globalizing World: Still Searching for the Basis of Contract, 14 IND. J. GLOBAL LEGAL STUD. 181, 181-90 (2007).

55. With certain sympathies for this perspective, see Berger, supra note 25.

56. See David Campbell, The End of Posnerian Law and Economics, 73 MoD. L. REV. 305, 312 (2010); see generally Simon Deakin, Social Rights in a Globalized Economy, in LABOUR RIGHTS AS HUMAN RIGHTS 25, 25-60 (Philip Alston ed., 2005); LUdwig RAISER, DIE ZUKUNFT DES PRIVATRECHTS (1971).

57. See Friedrich A. HAYek, The COnstitution of Liberty (1960), whose work has returned to new prominence in the context of the allegedly passing financial and economic crisis of our time; Hayek is being rediscovered as spokesperson against the paternalistic tendencies of the interventionist state. See Francis Fukuyama, Big-Government Skeptic, N.Y. TIMES, May 8, 2012, at BR12 (book review). The economist F.A. Hayek believed that no government could know enough to plan for society.

58. See, e.g., Michael Trebilcock \& Jing Leng, The Role of Formal Contract Law and Enforcement in Economic Development, 92 VA. L. REV. 1517, 1517-80 (2006); Richard A. Posner, Creating a Legal Framework for Economic Development, 13 WORLD BANK RES. OBSERVER 1, 1-11 (1998). 
abilities of market actors forgoes the opportunity to learn from the criticalhistorical evidence regarding legally constituted markets. In their place, we find social norms. ${ }^{59}$

But rather than reconnecting the proliferation of private ordering-which undoubtedly is occurring inside and outside of the nation-state-with the already available and highly effective legal-sociological and normative critique ${ }^{60}$ simplified renderings of transnational private ordering are offered. Lost are the insights into the recurring challenges of demarcating between public and private spaces of societal interaction and the "stakes" of such demarcations. ${ }^{61}$ The overwhelming challenges resulting from an emerging transnational legal, economic, and political order ${ }^{62}$ make the need to translate and to rethink national, historical learning experiences quite urgent.

A mediating, bridging perspective might be forthcoming through attempts at further scrutinizing the "public" dimensions of transnational private ordering that themselves bear important parallels with concurring efforts among public (international) lawyers to more concretely identify the public nature of international governance. ${ }^{64}$ Another promising opportunity might lie in a distinctly multi- and interdisciplinary analysis, ${ }^{65}$ above all, of the function of evolving rules, norms, and standards that have increasingly been taking the place of formal laws ${ }^{66}$ in the context of an irreversible shift from government to governance. Rather than trying to reattach these evolving regulatory forms to the (nation) state or to qualify them as examples of "private" ordering regimes,

59. See generally Richard H. McAdams, The Origin, Development, and Regulation of Norms, 96 MicH. L. REV. 338, 338-433 (1997) (emphasizing the significance of norms established by interacting market participants); Gillian K. Hadfield, The Many Legal Institutions that Support Contractual Commitments, in HANDBOOK OF NEW InSTITUTIONAL ECONOMICS 175, 191-92 (Claude Ménard \& Mary Shirley eds., 2005).

60. See the excellent analysis by Anna di Robilant, Genealogies of Soft Law, 54 AM. J. COMP. L. 499, 499-554 (2006), as well as the scathing critique of the neoliberal embrace of social norms by Daniela Caruso, Private Law and State-Making in the Age of Globalization, 39 N.Y.U. J. INT’L L. \& POL. 1, 1-74 (2006).

61. See A. Claire Cutler, Artifice, Ideology and Paradox: The Public/Private Distinction in International Law, 4 REV. INT'L POL. ECON. 261, 262 (1997); a monographical treatment is provided by CUTLER, supra note 21; see also the commentary by Peer Zumbansen, Sustaining Paradox Boundaries: Perspectives on Internal Affairs in Domestic and International Law, 15 EUR. J. INT'L L. 197, 197-211 (2004).

62. See, e.g., Nico Krisch, Beyond Constitutionalism: The Pluralist Structure of Postnational LaW (2010); PAUl SChiff Berman, Global Legal Pluralism (2012).

63. See RENNER, supra note 37, at 73 et seq., 87 et seq. (arguing that commercial arbitration has increasingly been freed from control through the state and public interests).

64. See Armin von Bogdandy, Philipp Dann \& Matthias Goldmann, Developing the Publicness of Public International Law: Towards a Legal Framework for Global Governance Activities, 9 GERMAN L.J. 1375, 1375-76 (2008).

65. See generally Oliver E. Williamson, THE MECHANISMS OF GOVERNANCE (1996); Elinor Ostrom, Challenges and Growth: The Development of the Interdisciplinary Field of Institutional Analysis, 3 J. InSTITUTIONAL ECON. 239, 240 et seq. (2007).

66. See generally Dieter Kerwer, Rules that Many Use: Standards and Global Regulation, 18 GOVERNANCE: INT'L J. POL'Y, ADMIN., \& INSTITUTIONS 611, 611-32 (2005) (focusing on the regulatory function performed by accounting standards). 
a particular focus on the different functional forms and dynamics of transnational governance appears to be more adequate, be they public or private, hard or soft, or official or unofficial. ${ }^{67}$

\section{IV}

\section{The Politics of Legal Theory AND Transnational Legal PluRALisM}

\section{A. Normative Conflicts in World Society}

One of the crucial lessons learned from the legal realist attack on formalism at the outset of the twentieth century was the emphasis on a critical engagement with functionalism. Rather than embracing a functionalist perspective on legal regulation in a wholesale turn against legal formalism dressed up as historically evolved, technical, and value neutral, the legal realists maintained a critical distance from the unavoidable ideological underpinnings of "scientific" and expert knowledge in the context of legal interpretation. ${ }^{68}$ It is this distance that requires our new attention in the context of engaging with different phenomena of transnational private regulatory governance of which the lex mercatoria is but one illustration. ${ }^{69}$ Compared to some of the aforementioned examples of transnational economic governance, the case of the lex mercatoria might not appear on its face as among the most obvious instances of legal-political critique. And yet, a closer scrutiny of the debate around this field is clearly warranted in light of at least two considerations. One consideration is that the lex mercatoria remains an arena that has seen conflicts between some of the furthest-reaching theoretical and normative assertions as regards the scope and nature of the institutions and processes that constitute this field. ${ }^{70}$ Another consideration concerns the wide scope of transnational economic governance constellations that are captured under the lens of the lex mercatoria, not least testified to by the staggering increase in cases brought before this system's quintessential institutional forum, the International Chamber of Commerce in Paris. ${ }^{71}$ The field is further deserving of our attention because of the way in which disputes over the system's merits have largely led to a primacy of a weighing of advantages (efficiency, discretion, costs) over an inquiry into the legal nature of the norms being invoked before transnational commercial arbitration tribunals. The impressive reality of this functioning of the system of

67. See Colin Scott, Regulatory Governance and the Challenge of Constitutionalism, (Eur. Univ. Inst. Robert Schuman Centre for Advanced Studies, Working Paper RSCAS 2010/07, 2010); Peer Zumbansen, Governance: An Interdisciplinary Perspective, in OXFORD HANDBOOK OF GOVERNANCE 83, 83-96 (David Levi-Faur ed., 2012).

68. See generally Felix Cohen, Transcendental Nonsense and the Functional Method, 35 COLUM. L. REV. 809, 809-49 (1935); JAMES LANDIS, THE ADMINISTRATIVE PROCESS (1938).

69. See Symposium, Transnational Private Regulatory Governance: Regimes, Dialogue, Constitutionalization, 13 GER. L. J. 1269 (2012).

70. For a fitting capture, see Alec Stone Sweet, The New Lex Mercatoria and Transnational Governance, 13 J. EUR. PUB. POL'Y 627, 637 (2006) ("The rise of the new Lex Mercatoria raises deep questions about the nature of law, and about the relationship of law to state power.").

71. Id. at 636 . 
the lex mercatoria feeds the enthusiasm of those who have long been arguing not only in support of the merits, but also of the purported autonomy of the lex mercatoria. ${ }^{72}$

One way, then, to disturb this elusive harmony would be to create tighter links between context analysis and the political arguments made in support of self-regulation and private autonomy. In that vein, the task would consist of searching for parallels between the particular regulatory and transactional context in which this turn to "private justice" is occurring ${ }^{73}$ on the one hand, and the calls for a de-judicialization of economic conflict resolution as they can be recorded within national debates about the roles of court ${ }^{74}$ about the political ambiguities of access to justice guarantees, ${ }^{75}$ and about the state in economic governance on the other. As alluded to at the beginning of this article, such a comparison between national and global discourses will likely show considerable parallels between an allegedly global, post-national context in which autonomous commercial parties take refuge to a comparably more "efficient," issue-oriented and discrete dispute resolution system on the one hand, and a national one, in which the complex economic nature of the commercial transaction before a court is being used as a justification to delegitimize undesired judicial "interventions," on the other.

The resulting task at this point is to bring together the observations regarding the contestation sites in international economic law, the contribution of global constitutionalism, and the critique of the hermeneutic justification strategies in the lex mercatoria on both the national and the global level. What emerges through a reading together of these three discourses is a confirmation that we are faced with a fundamental disembeddedness of law's institutional and instrumental response mechanisms' relation to social "problems" of a nature commonly associated with case law in the vein of Lochner. In fact, all three discourses give ample testimony to the precarious nature of law and legal regulation vis-à-vis (world) societal regulatory challenges. The question then becomes how to conceive of law in this situation as both a distinct discourse and as one among other societal rationalities. Clearly both the theoretical work around global constitutionalism and the lex mercatoria suggest that the boundaries of law have become porous: much of what (comparative and) global constitutionalists are concerned with touches on the boundaries of law and nonlaw, law and politics, and law and morality. The challenge for global

72. See generally GAILLARD, supra note 4; BERGER, supra note 5.

73. P.H. Lindblom, The Privatization of Justice: Some Aspects of Recent Developments in American and Swedish Procedural Law, 39 NETH. InT'L L. REV. (SPECIAL IsSUe S1) 199, 199-214 (1992) (describing, from a comparative perspective, the transformation of the judiciary in the aftermath of the Cold War).

74. See, e.g., WolfGang Hoffmann-RIEM, Modernisierung VOn ReCHT Und JUSTIZ. EINE HERAUSFORDERUNG DES GEWÄHRLEISTUNGSSTAATES (2001) (offering a comprehensive analysis of the increasing shift of the German judicial system to alternative forms of conflict resolution and mediation).

75. See generally Héctor FIX-Fierro, COURTS, Justice AND EFFICIENCY: A SOCIO-LeGAL STUDY OF ECONOMIC RATIONALITY IN ADJUDICATION (2004). 
constitutionalists is to imagine constitutionalism in very diverse settings, marked by different evolutionary stages of statehood, formal order, and informal order. ${ }^{76}$ Meanwhile, lex mercatoria scholars are asked to conceptualize a legal methodology that captures the intricate intersections and overlaps between public and private rule-setting processes and adjudication institutions. Finally, the dilemmas that arise in international economic law cut straight across these constellations as they illustrate the manifold challenges of crafting legal responses to border-crossing, self-regulatory activities, which are-as in the exemplary cases of investment law and mining - at the same time heavily marked by a conflict between private rights and public policy, between what David Schneiderman referred to as instantiations of a tension between "new constitutionalism" and governmental regulatory prerogatives. ${ }^{77}$

A striking impression from a parallel observation of global constitutionalism, the lex mercatoria, and international economic law is how these sites of legal-political conflict illustrate together a number of challenges to law that have long marked legal regulation in the Western evolution of rule of law to social state on to the ambivalent constellation that has emerged from the decline of the welfare state. As noted earlier, the tension between formal and informal orders, between the state's assumption of formulating overarching policies and the resulting tensions from conflicts with competing societal rationalities such as economics, religion, or science are not distinct for the current constellation of world society. They have, instead, marked the evolution of Western nation-states for a long time. But world society today exposes the fragility of the overall frameworks, which find expression in references to constitutionalism and market regulation. These frameworks, recently still associated with the evolution of a particular, often nationally institutionalized constitutional order and relatively recognizable frontiers between competing conceptions of "state" and "market," "78 are today no longer available except with references to particular historically and locally conceived evolutionary narratives. In contrast, the world societal setting opens up a vista on endless confrontations and conflicts between different interest formations, rationalities, and stakes. It is against this background that the three legal discourses we identified illustrate the trials of law's attempts to adapt to these changing conditions.

In other words, these three constellations prompt a reconsideration of legal methodology in light of the profound loosening of the state-law nexus in a

76. See, e.g., Ulrich Sieber, Legal Order in a Global World. The Development of a Fragmented System of National, International, and Private Norms, in 14 MAX PLANCK Y.B. UNITED NATIONS L. 1, $1-49$ (2010).

77. David Schneiderman, Investment Rules and the New Constitutionalism, 25 LAW \& SoC. INQUIRY, 757, 758 (2000) ("The new constitutionalism refers to the quasi-legal restructuring of the state and the institutionalization of international political forms that emphasize market credibility and efficiency and also limit the processes of democratic decision making within nation states.").

78. Compare generally KARL POLANYI, THE GREAT TRANSFORMATION (1944), with FRIEDRICH HAYEK, THE ROAD TO SERFDOM (1944) and HAYEK, supra note 57. 
global context. In the 1950s Philip Jessup suggested the term "transnational law" to identify a legal response to those border-crossing activities which were not adequately captured by either conflict of laws (private international law) or public international law. ${ }^{79}$ Arguably, already for Jessup, transnational law could be conceived of as a label for a legal "field," as much as a conceptual framework within which to investigate the arguments used to demarcate "national" and "transnational" spheres of legal regulation. Today, with the context of such investigations having changed considerably, the juxtaposition of territorially confined and global spaces is just one among others through which we try to make sense of the complex world societal relations with regard to which we reascertain the nature and the role of law.

As a result, a concept of transnational law must embrace this constellation in the hope of offering a methodology in response to it. In this process, transnational law might become but a short-hand for a methodological inquiry into the nature of law in a global context. ${ }^{80}$ Namely, from a methodological perspective, the tensions between national and global, between public and private, and between law and non-law can be understood as constitutive elements of an emerging understanding of the law of world society. These tensions are constitutive and inherent to world society law, because they illustrate the unavoidable ambivalence-politically, culturally, and morally—of competing and colliding ordering paradigms, alongside of which law seeks to express and assert itself. And it is from a methodological perspective that individual areas of law can be understood as a showcase of the struggle for law ${ }^{81}$ in the context of a radically changed institutional and regulatory landscape. ${ }^{82}$

Transnational law, understood as a legal-theoretical, legal-methodological approach, prompts us to study the emergence of hybrid, unruly, and messy regulatory regimes as instantiations of an evolving legal rationality in the context of world society. In other words, transnational law scrutinizes the nature of the distinction between law and non-law, which it understands as an expression of its own need to define its relation to society. In this vein, transnational law cannot remain confined to a study of only legal theory, legal doctrine, or legal history. Instead, the nature and role of law in world society must be ascertained through a multi- and interdisciplinary investigation into the forms and dynamics of societal regulation.

79. Philip C. Jessup, Transnational LaW 2 (1956). See generally Christian Tietje \& Karsten Nowrot, Laying Conceptual Ghosts of the Past to Rest: The Rise of Philip C. Jessup's 'Transnational Law' in the Regulatory Governance of the International Economic System, 50 BEITRÄGE ZUM TRANSNATIONALEN WIRTSCHAFTSRECHT [ESSAYS IN TRANSNATIONAL ECONOMIC LAW] 17, 17-43 (2006).

80. For background, see generally Peer Zumbansen, Transnational Law, Evolving, in ElGAR ENCYCLOPEDIA OF COMPARATIVE LAW 898, 898-925 (Jan Smits ed., 2d ed. 2012); Peer Zumbansen, Transnational Legal Pluralism, 1 TRANSNAT'L LEgAL THEORY 141, 141-89 (2010) [hereinafter Zumbansen, Transnational Legal Pluralism].

81. RUdOlF VON JHERING, THE STRUGGLE FOR LAW 21 (J. Lalor trans., 2d ed. 1915).

82. Sweet, supra note 70 , at 637. 


\section{B. The Promise of Legal Pluralism}

Such an investigation must draw on extensive empirical and ethnographic studies, as has long been standard in legal anthropological research. Through such an approach, the formation of norm-setting processes becomes visible from within highly specialized and localized contexts. From a legal anthropological perspective, the attribution of such processes and institutions to either a "national" or "global" level is of less significance than the illumination of the concrete context out of which norms are being formed and institutionalized. Legal pluralists, by drawing on anthropological and sociological accounts to more adequately capture the dynamics of normcreation and regulatory practice, scrutinize the distinction between a legal and a social norm to better understand the concrete process through which a norm comes into existence and is adhered to or rejected. The distinction between law and non-law, then, doesn't serve as a yardstick to differentiate between a "valid" or "invalid" norm, between binding or non-binding, but as one which can explain the discursive context in which such qualities are being ascribed to either. As such, a view that radically relativizes an otherwise accepted connection between valid legal norms and a particular institutional framework to generate such norms ${ }^{83}$ which are of interest mostly from a historiographical perspective ${ }^{84}$ holds great promise for a study of norm-generating processes in the global context. Rather than demarcating between formal and informal, legitimate and illegitimate sources of law, global or transnational legal pluralist approaches ${ }^{85}$ start from the concrete context "on the ground." Through this lens, the discursive constructions of the meaning of formal and informal, legitimate and illegitimate, and public and private become discernible. As such, it becomes possible to explain the emergence of particular connotations and attributions against the background of specific historical, evolutionary patterns, but such an inquiry does not answer the question how to distinguish between law and non-law in a categorical way. Instead, the legal pluralist and legal anthropological approaches help us understand the circumstances and influences that contribute to the characterization of a norm in this way or another. ${ }^{86}$ Transnational "law" can thus be reconceived as transnational legal pluralism in that it methodologically responds to the fragmented, disembedded evolutionary dynamics of norm-creation in the context of world society.

83. See generally AdDa B. Bozeman, The Future of LAW in a Multicultural World (1971).

84. See Niklas Luhmann, Verfassung als evolutionäre Errungenschaft, 9 RECHTSHISTORISCHES JOURNAL 176, 176-220 (1990) (Ger.) (tracing the emergence of constitutional norms as part of the differentiation and consolidation of political systems).

85. See the conceptual proposals by BERMAN, supra note 62; Ralf Michaels, Global Legal Pluralism, 5 ANN. REV. L. \& SOC. SCI. 243, 243-62 (2009); Zumbansen, Transnational Legal Pluralism, supra note 80 , at 167.

86. See generally ARTHURS, supra note 33 . 


\section{The Elusive Status of the Political in World Society}

But what about the politics? How can a transnational legal pluralist approach adequately respond to the conflicts we have alluded to earlier with reference to global constitutionalism and international economic law, and which are inherent to the lex mercatoria? ${ }^{87}$ An answer depends on the degree to which the legal anthropological or pluralist lens allows for a better understanding of how "interests" and "stakes" find expression. In other words, the "deliverable" of this approach is not seen in the formulation of a programmatic or principled political (normative, or critical) viewpoint. Instead, the task is to lay bare the processes through which views are being formulated, through which they become dominant or defeated, institutionalized or squashed. The fastproliferating anthropological investigations into deeply contested conflict zones such as those alluded to earlier ${ }^{88}$ give ample testimony of the significance of further enriching and concretizing the description of the site of conflict. It is only against this background that we may begin to understand the particular, evolving nature of "political" struggles, claims, and processes in a transnational context.

Let us return now, one last time, to our example of the lex mercatoria and to the significant political ambiguities underneath the surface of such a fastevolving regulatory regime. The already depicted hiatus between national discourses regarding overburdened, "incompetent" courts and the transnational aspiration to an autonomous, self-regulatory order is an interesting tale about the construction of meaning and the power of polemics. In light of the proposal to "short-circuit" national and transnational regulatory discourses in the hope of thus identifying common challenges as well as insights (and blind spots), it appears that the hiatus depicted here results, above all, from an unwarranted demarcation of the two spheres when it comes to identifying their respective constitutive qualities.

Arguably, the line-drawing between national and global assertions of the roles of courts in economic governance and market regulation results in a depoliticization of the respective governance constellations. The turn away from the national as "traditional" and the turn toward the "transnational" ${ }^{\circ 9}$ in fact cuts the ties between a space associated with (endless ${ }^{90}$ ) politics and one strangely untouched by such quarrels. Echoing Stone Sweet's keen observation of lex mercatoria's aspirations for an a-national regulatory regime, ${ }^{91}$ we can find an intriguing illustration of how "denationalization" $"$ functions in fact as an

87. See generally CUTLER, supra note 21 .

88. See supra text accompanying note 77 .

89. See generally BERGER, supra note 5.

90. Carl Schmitt, State Ethics and the Pluralist State, in WeIMAR: A JURISPRUdENCE OF CRISIS 300, 300-12 (Arthur J. Jacobson \& B. Schlink eds., Belinda Cooper et al trans., 2000) (providing a famous description of the challenges posed to the concept of a sovereign and unitary state by a pluralistic society).

91. Sweet, supra note 70 , at 633 .

92. Sassen, supra note 13, at 1-22 (offering an analysis of how state actors are facilitating processes 
immunization of a sphere of societal interaction from political critique. Taking arguments of expediency and economic efficiency at face value to prioritize private arbitration tribunals over national courts, an entire body of experience with evolving judicial systems, adjudication, and conflicts over rights is being made irrelevant.

Meanwhile, continuing national debates about the reform of the judicial system illustrate the stakes and vulnerabilities in this context. These dimensions of the judicial system no longer come into view in the context of the lex mercatoria, as the entire system is understood to be available and of service only to those who engage in transnational economic activity and who have chosen to have a possible legal conflict with their business partner(s) resolved through an arbitration process. Such a narrow characterization of the transnational arbitration system, however, understates the significance of the arbitral system in a larger context of private transnational economic governance, which is brought about by a large-scale privatization of normgeneration, implementation, and enforcement. This in turn raises pressing questions regarding the "public" dimensions, responsibilities, and protections available to all those "affected."

Opening up such a comparative perspective on national and global sentiments with regard to the role of courts in economic governance, we may be able to see striking parallels between the resistance against "incompetent" courts on the national level and the claim for an autonomous legal order in the transnational sphere. But, with these parallel insights, the blind spots and intentional omissions of this embrace of private justice also become visibleinside and outside of the nation state. Questions of context, externalities, and stakeholders become ones that are of concern allegedly only from a policy perspective, which is seen as somehow external to both the conflict at hand and the institutional regime designed to handle it.

This isolation of a particular conflict between two competing rights positions from the larger socio-economic and legal context, in which any assertion of rights and their scope must take place, is a well-known move in legal-political argument. ${ }^{94}$ The demands for a more "efficient" judicial system to handle economic conflicts have dramatic consequences for the opportunities of verbalizing and thematizing the hereby neglected and invisibilized externalities and affected interests. Whereas debates about court reform in the context of the

of deregulation that are often associated with processes of globalization and with accounts of the state as a "victim" of globalization).

93. RENNER, supra note 37, at 24-25; see Regina Kreide, The Ambivalence of Juridification. On Legitimate Governance in the International Context, 2 GLOBAL JUST.: THEORY PRAC. RHETORIC 18, 28-29 (2009) (on the criterium of "affectedness" as a crucial element in an emerging transnational political-legal order); Roger Cotterrell, What is Transnational Law?, 37 LAW \& SOC. INQUIRY 500, 500-24 (2012) (reviewing von Daniels' The Concept of Law from a Transnational Perspective and Calliess \& Zumbansen's Rough Consensus and Running Code: A Theory of Transnational Private Law).

94. See, e.g., Lochner v New York, 45 U.S. 198 at 74-76 (1905) (Holmes, J., dissenting). 
nation state would not be possible without a consideration of the historically evolved role of the courts as well as of the encompassing constitutional framework, the claim for private justice seeks to free itself from any such context. As a result, the underlying challenge of conceptualizing a judicial system which satisfies comprehensive demands for an "access to justice" is seen as having little relevance for the merchant client-oriented system of transnational commercial arbitration. By isolating and underscoring the advantages of a streamlined, privatized, and expedient dispute resolution system, such calls for an autonomous arbitration order result in a more encompassing dismissal of a historically grown judicial culture, which has long been understood as an essential element of the evolution of the rule of law. An important dimension of this experience has for some time found expression in a renewed interest in questions of access, acceptance, and compliance among those that a judicial system is designed to serve. Such concerns are formulated in the context of a far-reaching frustration with the inadequate functioning of rule-of-law institutions ${ }^{96}$ but also in new, emerging contexts of alternative conflict resolution in precarious post-conflict constellations. ${ }^{97}$

These two examples precisely underscore the importance of taking the larger context into view out of which norm-generating and adjudication processes are forming today-but out of which such processes have always been emerging. Rather than testifying to attempts at returning to ambitious programs of court-driven social engineering, the emphasis on context is motivated by the need for a much richer and better-informed account of a problem to be turned into a "case" - today as in the past. This context defies "political," normative "answers." Instead, it prompts an incessant inquiry into the different venues and fora through which stakes are being identified and expressed. In that regard, the focus shifts away from the normative focus on the content of a particular interest or stake to a scrutiny of the challenges in giving expression to all viewpoints and factors which inform and shape a particular problem. This observation allows us to connect the legal pluralist work, say, as it began to critically engage with the legal system in the Western welfare state of the $1970 \mathrm{~s},{ }^{98}$ with the rich anthropological and legal-sociological work that is being carried out today. The politics, then, are in the process of making visible the competing interests and viewpoints. This is the background against which we must henceforth look for legal responses.

95. See, in particular, the project by Mauro Cappelletti and Bryant Garth, Access to Justice: The Worldwide Movement to Make Rights Effective. A General Report, in 1 ACCESS TO JusTICE: A WorLD SURVEY 3, 3-124 (Mauro Cappelletti \& Bryant Garth eds., 1978).

96. See, e.g., Marc Galanter, Why the "Haves" Come Out Ahead: Speculations on the Limits of Legal Change, 9 LAW \& SOC'Y REV. 95, 150 (1974).

97. See generally the contributions in TRANSITIONAL JUSTICE IN THE TWENTY-FIRST CENTURY: BEYOND TRUTH VERSUS JUSTICE (Naomi Roht-Arriazza \& Javier Mariezcurrena eds., 2006).

98. See, e.g., Marc Galanter, Justice in Many Rooms: Courts, Private Ordering, and Indigenous Law, 19 J. LEGAL PluRALISM 1, 1 (1981). 
In other words, the legal pluralist's focus on context complements the discursive analysis, which we have identified as being crucial to lay bare the otherwise hidden political assumptions of the calls for an autonomous transnational legal order. A central concern of such scrutiny must be to question readily found demarcations between "economic" and "other" issues or interests, as they inform many of the arguments made against judicial "incompetence" and "intervention." with assertions such as these. A demarcation of economic and non-economic issues, the latter of which Gillian Hadfield labels "justice," risks missing the complexity of just about any "economic" problem. ${ }^{100}$ This would be true now as it was a long time ago. ${ }^{101}$

To the degree that the legal depiction of a particular social situation or "problem" is always the result of an "alienation" and complex form of translation of the social facts-by way of identification and construction of a specific constellation of interests $\mathrm{s}^{102}$-into the rationality of the law, this process itself must be accounted for in legal methodology. We thus need to take seriously that any legal appropriation of a social conflict is always already impregnated by a number of competing societal rationalities (such as economics, politics, and religion), which enrich, complement, but also disturb the legal account. The necessity to lay bare the way in which such different elements find their way into the legal depiction of a problem had long been identified by a sociological and pluralist legal theory when asking what lies "behind a case."

The coalescence of a widespread disillusionment with the promises of "free markets," 103 the significant insights from the "law and development" movement, ${ }^{104}$ along with a powerful, anthropologically informed human rights critique $^{105}$ illustrates the promises of a legal theory that places a distinct

99. Gillian K. Hadfield, The Public and the Private in the Provision of Law for Global Transactions, in CONTRACTUAL CERTAINTY IN INTERNATIONAL TRADE: EMPIRICAL STUDIES AND THEORETICAL DEbATES ON INSTITUTIONAL SUPPORT FOR GLOBAl ECONOMIC EXCHANGES 239, 241-255 (Volkmar Gessner ed., 2009). For a critical rebuttal, see GRALF-PETER CALLIESS \& PEER Zumbansen, Rough Consensus and Running Code: A THEORY of Transnational Private LAW 27-152 (2010).

100. See, e.g., Ostrom, supra note 65, at 239-64.

101. See Cohen, supra note 29, at 8-30; Cohen, supra note 48, at 553-92.

102. See generally Teubner, supra note 53, at 388-404; Gunther Teubner \& Peer Zumbansen, Rechtsentfremdungen: Zum gesellschaftlichen Mehrwert des zwölften Kamels, 21 ZEITSCHRIFT FÜR RECHTSSOZIOLOGIE 189, 189-215 (2000) (Ger.) (outlining a theory of law's appropriation of a social conflict and its transposition into a justiciable "case").

103. For a critique, see generally JOSEPH E. STIGLITZ, GLOBALIZATION AND ITS DisCONTENTS (2002).

104. See generally David Trubek, Toward a Social Theory of Law: An Essay on the Study of Law and Development, 82 YALE L.J. 1, 1-50 (1972); David M. Trubek \& Marc Galanter, Scholars in SelfEstrangement: Some Reflections on the Crisis in Law and Development Studies in the United States, 1974 WIS. L. REV. 1062, 1062-1101.

105. See Richard Ashby Wilson, Tyrannosaurus Lex: The Anthropology of Human Rights and Transnational Law, in THE PRACTICE OF HUMAN RIGHTS: TRACKING LAW BETWEEN THE GLOBAL AND THE LOCAL 342, 342-69 (Mark Goodale \& Sally Engle Merry eds., 2007); Sally Engle Merry, New 
emphasis on a close study of the particular dynamics of societal norm-creation and conflict resolution. The lex mercatoria of the future still has to take that methodological step rather than stay confined to a world view shaped by distinctions between economic and non-economic or national and global. Only by reorienting its analytical focus toward the diverse contexts of legal conflict constellations will it be possible to unearth the liens between a "transnational legal theory" so desired by the promoters of the lex mercatoria, ${ }^{106}$ and the actually ongoing efforts in search of a "better" justice system-nationally, internationally, locally, and globally. 